\section{B A Institute of \\ yk Business Administration \\ 六下 \\ Karachi \\ Leadership and Ideas for Tomorrow}

\section{Business Review}

Volume 5 Issue 1 January-June 2010

$1-1-2010$

\title{
Comparative analysis of Islamic and conventional banking performance
}

\author{
Mirza Ali Huzaifa Sultan \\ NU-FAST Business School, Karachi \\ Muhammad Zahid Siddique \\ NU-FAST Business School, Karachi
}

Follow this and additional works at: https://ir.iba.edu.pk/businessreview

Part of the Finance and Financial Management Commons, and the Islamic Studies Commons

\section{(c) ()}

This work is licensed under a Creative Commons Attribution 4.0 International License.

\section{Recommended Citation}

Sultan, M. A., \& Siddique, M. Z. (2010). Comparative analysis of Islamic and conventional banking performance. Business Review, 5(1), 91-116. Retrieved from https://doi.org/10.54784/1990-6587.1259

This article is brought to you by iRepository for open access under the Creative Commons Attribution 4.0 License and is available at https://ir.iba.edu.pk/businessreview/vol5/iss1/7. For more information, please contact irepository@iba.edu.pk. 


\title{
ARTICLE
}

\section{Comparative Analysis of Islamic and Conventional Banking Performance}

\author{
Mirza Ali Huzaifa Sultan \\ NU-FAST Business School, Karachi \\ Muhammad Zahid Siddique \\ NU-FAST Business School, Karachi
}

\begin{abstract}
This paper analyzes the performance of Islamic banks compared to that of conventional banks in Pakistan. This comparison is based on the financial performance, product services and customer perception. We have selected two Islamic banks, namely Meezan Bank limited \&Albaraka Bank, and two conventional Banks, Soneri and My Bank. This selection was made because of the similar size of these banks in terms of their deposits. The paper shows that Islamic Banking is falling behind the conventional one both in terms of its business as well as customer perspective.
\end{abstract}

The research is divided into three parts. First part covers the comparison of financial analysis between Islamic and conventional banks in Pakistan over last five years. For financial analysis, sixteen ratios are selected and are grouped in five major groups namely: profitability; liquidity; business development; efficiency and solvency ratios. The hypothesis is generated to rank the financial health of each bank. The second part compares the products services of Islamic and Conventional banks. This product service comparison is done on the basis of deposits, financing and services. For this deposits and certificates accounts are compared in terms of return or profit they are offering to their customers. Financing part measures the differences of car and home financing between Islamic and conventional banks. Last section of this part measures the difference of services that are provided by the respective banks to their customers. The final part of this research identifies the customer perception about Islamic and conventional banks. For this, a survey analysis is conducted from different customers of both Islamic and conventional banks. In this survey analysis, the rationale is to identify which banking system is preferred by customers. It is concluded that customers prefer Islamic banks rather than conventional banks.

\section{JEL Classification: G21}

Key words: Islamic banking, financial ratios, bank services, conventional banking, comparison 


\section{1: INTRODUCTION}

\section{1:Background}

Banks play a vital role in every day's business life. Bank as an institution, deals in money and its substitutes and provide other financial services. Banks accepts deposits and gives loans and derives a profit from the difference in the interest rates paid. Islamic banks will fit this description only just even if one replaces 'interest rates paid' with 'profit-shares and fees'. (Ariff, 2007) After almost four decades of establishment, Islamic banks have managed to place themselves as financial organizations not only playing vital role in resource mobilization, resource distribution and consumption but are aggressively involved in the process of executing government monetary policy. Apart from offering almost all conventional banking facilities, Islamic banks also make possible local and foreign trades. So evaluation of Islamic bank performance is important for all parties: depositors, bank managers and regulators as it is vital for other commercial banks. The combination of global financial markets has put Islamic banks in a severe competition with traditional banks. To battle in local and global deposit markets, Islamic banks have planed and innovate, Islamically acceptable instruments that have coped with the constant innovations in financial markets. (Mehmood, 2005). This study is divided in to seven chapters. First and Second Chapters describe the Introduction and Literature Review for this research. Third Chapter deals with methodology plan for conducting this research study. The findings and interpretation are divided in to three chapters which are Chapter 4 deals with financial analysis, Chapter 5 deals with Product Service comparison and Chapter 6 deals with Customer Perception. Last Chapter concludes this research study and gave some recommendations for both banks.

\subsection{Objectives}

The main objective of this research is to do a comparative analysis of Islamic banks with conventional banks and to identify which banking system is going well according to their performance. The performances of these two banking systems are identified according to financial analysis, product service comparison and customer view point about Islamic and conventional banking.

This research study will also determine some key questions which are:

- What are the financial performances of Islamic Banks with respect to Conventional banks over last five years?

- What are the differences between Islamic products and Conventional products?

- What are the customer viewpoints about Islamic and Conventional Banks? 


\subsection{Research Scope}

The scope of this research is to compare the performance of Islamic and conventional banks in Pakistan on the basis of their financial performance, product service comparison and customer perception about Islamic banking. The basic proposal of this research is to evaluate the success of Islamic banking as compared to conventional banks. Islamic banking is quite an old concept but it has taken many observers by surprise. What is more, the pace with which Islamic banks have come up and the rate at which they have developed makes it valuable to study them analytically. Islamic banking with its initial boom is proposed to grow as Islamic banking is continuously growing and many conventional banks have also started operating their separate Islamic branches that are completely dedicated to Islamic finance.

\section{2: LITERATURE REVIEW}

This section deals with some basic review of literature. The major research studies that have been conducted in line with this research are a case study by Farrukh (2005) of PAF-KIET has been done on "Comparative performance of two Islamic and two Commercial Banks". The author compared financial banks of two banks. Mehmood (2005) from Bradford School of Management has also done a research study on "Islamic Banking: A performance comparison of Islamic bank versus conventional bank in Pakistan". In this research the author compares the financial performance of the two banking systems in Pakistan. Kader (2005) has done a research on "Financial Performance of Islamic Banks via Conventional Banks in the UAE". Kader compares the Islamic and conventional banks in UAE. Samad (2004) research study published in Malaysia with the title "Performance of Interest free Islamic Banks via Interest based Conventional Banks of Bahrain". Anwar (2000) conducted a research on "Islamicity of Banking and Modes of Islamic Banking" in Malaysia.

The research studies that are conducted in countries like UAE, Bahrain, Malaysia and Pakistan even are just focusing on financial performance. Therefore this research not only focuses on comparing financial performance of Islamic and conventional banking but also product and service comparison. In product and service analysis the focus is on comparing products and services of both Islamic and conventional bank and find which bank are providing better products and services to customers.

\section{3: METHODOLOGY PLAN}

The methodology plan for this research is divided into different sections, which are explained below: 


\subsection{Strategy}

Financial Management theories provide various indexes for measuring a bank's performance. One of them is accounting ratios. The use of the financial ratios is quite common in literature, as these are valuable analytical tools used to measure the financial health of a bank. Financial ratios are also widely used to forecast the future success of companies and to develop models exploiting these ratios. The basic strategy is to measure the health of both Islamic and Conventional banks over five year period.

The strategy for conducting the product service comparison is to compare the products and services of Islamic and Conventional banks in term of deposits, financing and services. The rationale for doing this comparison is to identify which banking system is providing better rates, quality products and fast services.

The strategy for identifying customer perception on Islamic and Conventional banking is to conduct a survey through questionnaire. Both conventional and Islamic banks customers are used for this purpose. The rationale is to identify the customer's response about which banking system they prefer.

\subsection{Sample Selection}

For conducting financial and product service analysis between Islamic and conventional banks, two Islamic banks; Meezan Bank Limited \& Bank Albaraka; and two conventional banks; Soneri Bank Limited \& My Bank Limited are selected. The selected banks are broadly of similar size in terms of deposits. We have compare Meezan Bank Limited with Soneri Bank Limited and Bank Albaraka with My Bank Limited because of their similar size in terms of deposits.

To identify the customer perception about Islamic and conventional banks a survey is conducted in different banks of Karachi from people of different ages including both males and females. Altogether one hundred samples are selected. The sample includes for this survey are: Bank Alfalah Limited; Meezan Bank Limited; Soneri Bank Limited; Habib Bank Limited; Untied Bank Limited; Faysal Bank; Bank Al-Habib Limited; Mybank Limited; NIB Bank and Bank Albaraka.

\subsection{Hypothesis}

A hypothesis has been generated in financial analysis for this research. The statistical method of t-test has been used at 0.05 level of significance to identify 
the significant difference. The null hypothesis is "The performance of Islamic banks is equivalent to conventional banks". The hypothesis is rejected (if performance significantly differs) or rejected (if performance not significantly differs) for each ratio.

\subsection{Statistical tools}

The statistical tools that are used in this financial analysis are mean, t-test. Mean is used to calculate the average mean of last five years of both Islamic and Conventional banks. Meanwhile for survey analysis, the statistical tools used are mean, standard deviation, cross tabulation of different questions and descriptive statistics.

\subsection{Data Collection}

The data for conducting financial analysis are compiled from income statement and balance sheets of selected banks. The financial data of the four banks are collected from annual reports of last five years. Specific ratios are used for this research instrument. This study uses sixteen ratios for bank's performance. These ratios are grouped under five broad categories: (a) profitability; (b) liquidity; (c) business development; (d) efficiency; and (e) risk and solvency. Meanwhile product service analysis data are gathered from personal contacts, interviews and website.

\section{4: FINANCIAL ANALYSIS}

This section deals with financial analysis that is conducted between two Islamic banks that are Meezan Bank Limited \& Bank Albaraka and two conventional banks that are Soneri Bank Limited \& My Bank Limited. This study uses eighteen ratios for bank's performances which are grouped under five categories.

The findings of ratio analysis of Islamic and Conventional banks for the period of 2002-2006 have been calculated for evaluation. The statistical method of t-test has been used at 0.05 level of significance to identify the significant difference. The null hypothesis is "The performance of Islamic banks is equivalent to conventional banks". Following are the findings of ratio analysis: 


\begin{tabular}{|c|c|c|c|c|c|c|c|c|c|c|c|}
\hline \multirow{3}{*}{ Performance Measures } & \multicolumn{10}{|c|}{ Ratios with respect to Last Five Years } & \multirow{3}{*}{$\begin{array}{c}\text { Statistic Test } \\
\text { T-Value } \\
\text { Accept or Reject }\end{array}$} \\
\hline & \multicolumn{5}{|c|}{ Islamic Banks } & \multicolumn{5}{|c|}{ Corventional Banks } & \\
\hline & 2002 & 2003 & 2004 & 2005 & 2006 & 2002 & 2003 & 2004 & 2005 & 2006 & \\
\hline \multicolumn{12}{|l|}{ 1. Profitability } \\
\hline a. Return on Asset & $2.5 \%$ & $1.7 \%$ & $1.3 \%$ & $2.1 \%$ & $1.2 \%$ & \begin{tabular}{|l|}
$0.7 \%$ \\
\end{tabular} & $0.7 \%$ & $0.1 \%$ & $0.5 \%$ & $0.4 \%$ & 1.67(2.31) Accept \\
\hline b. Return on Equity & $13.1 \%$ & $10.2 \%$ & $9.9 \%$ & $16.3 \%$ & $10.9 \%$ & $7.8 \%$ & $8.0 \%$ & $14.6 \%$ & $18.9 \%$ & $16.3 \%$ & $-0.41(2.45)$ Accept \\
\hline c. Yield on Earning Asset & $2.9 \%$ & $2.3 \%$ & $1.9 \%$ & $3.8 \%$ & $1.1 \%$ & $1.9 \%$ & $0.6 \%$ & $0.3 \%$ & $0.7 \%$ & $1.2 \%$ & $2.75(2.36)$ Reject \\
\hline d. Cost of Funds & $4.6 \%$ & $2.5 \%$ & $1.9 \%$ & $3.7 \%$ & $5.2 \%$ & $4.9 \%$ & $1.9 \%$ & $1.6 \%$ & $3.2 \%$ & $5.6 \%$ & $0.13(2.31)$ Accept \\
\hline e. Net Profit Margin & $49.7 \%$ & $41.6 \%$ & $39.1 \%$ & $40.5 \%$ & $17.6 \%$ & $8.6 \%$ & $10.8 \%$ & $24.2 \%$ & $25.9 \%$ & $23.5 \%$ & 2.94(2.36) Reject \\
\hline f. Spread & $-1.7 \%$ & $-0.2 \%$ & $0.0 \%$ & $0.1 \%$ & $-4.1 \%$ & $-3.0 \%$ & $-1.4 \%$ & $-1.3 \%$ & $-2.5 \%$ & $-4.4 \%$ & 1.37(2.36) Accept \\
\hline \multicolumn{12}{|l|}{ 2. Liquidity } \\
\hline a. Cash to deposit & $19.4 \%$ & $17.9 \%$ & $23.0 \%$ & $23.8 \%$ & $20.7 \%$ & $13.8 \%$ & $12.0 \%$ & $12.6 \%$ & $10.1 \%$ & $10.4 \%$ & $7.11(2.36)$ Reject \\
\hline b. Advances to deposit & $80.9 \%$ & $92.8 \%$ & $87.8 \%$ & $78.3 \%$ & $74.3 \%$ & $48.9 \%$ & $62.6 \%$ & $65.7 \%$ & $69.8 \%$ & $68.6 \%$ & $3.88(2.31)$ Reject \\
\hline \multicolumn{12}{|l|}{ 3. Business Development } \\
\hline a. Total Asset growth & $B Y^{*}$ & $138 \%$ & $214 \%$ & $309 \%$ & $448 \%$ & $B Y^{*}$ & $122 \%$ & $152 \%$ & $194 \%$ & $252 \%$ & 1.34(2.78) Accept \\
\hline b. Deposit growth & BY* & $138 \%$ & $212 \%$ & $321 \%$ & $468 \%$ & $B Y^{*}$ & $126 \%$ & $161 \%$ & $199 \%$ & $252 \%$ & 1.31(2.78) Accept \\
\hline c. Advances growth & $\mathrm{BY}^{*}$ & $165 \%$ & $246 \%$ & $353 \%$ & $481 \%$ & $B Y^{*}$ & $165 \%$ & $217 \%$ & $282 \%$ & $360 \%$ & $0.69(2.57)$ Accept \\
\hline d. Earning growth & $\mathrm{BY} *$ & $80.0 \%$ & $93.8 \%$ & $212 \%$ & $185 \%$ & $B Y^{*}$ & $-213 \%$ & $1235 \%$ & $3880 \%$ & $6879 \%$ & -1.8(3.18) Accept \\
\hline \multicolumn{12}{|l|}{ 4. Efficiency } \\
\hline a. Assets Utilization & $5.4 \%$ & $3.5 \%$ & $2.8 \%$ & $4.6 \%$ & $5.9 \%$ & $6.3 \%$ & $4.5 \%$ & $4.0 \%$ & $5.9 \%$ & $7.1 \%$ & $-1.35(2.31)$ Accept \\
\hline b. Operating Efficiency & $71.1 \%$ & $96.7 \%$ & $315 \%$ & $272 \%$ & $494 \%$ & $136 \%$ & $174 \%$ & $272 \%$ & $207 \%$ & $121 \%$ & $0.82(2.57)$ Accept \\
\hline \multicolumn{12}{|l|}{ 5. Risk and Solvency } \\
\hline a. Debt to total assets & $81.3 \%$ & $85.6 \%$ & $86.8 \%$ & $87.0 \%$ & $89.1 \%$ & $90.6 \%$ & $91.9 \%$ & $90.8 \%$ & $89.1 \%$ & $86.5 \%$ & $-2.42(2.36)$ Reject \\
\hline b. Equity Multiplier & $563 \%$ & $700 \%$ & $787 \%$ & $817 \%$ & $918 \%$ & $1084 \%$ & $1259 \%$ & $1226 \%$ & $1059 \%$ & $892 \%$ & -3.91(2.31) Reject \\
\hline
\end{tabular}

\subsection{Profitability Ratios}

The return on assets ratio of Islamic banks is higher than conventional banks. For Islamic banks, ROA decreases in 2004, but rises in 2005 and again decreases in 2006. For conventional banks, it is exactly same as Islamic banks. So, at the $5 \%$ confidence level, we can say that ROA ratios of both Islamic and conventional banks don't significantly differ. The Return on Equity of Islamic banks is also higher than the conventional banks in 2002 and 2003, while in later years 20042006 the ROE is higher for conventional banks. However, from the Table 4.1, we can see that in the year 2005, the ROE for both, conventional banks has rise to $18.9 \%$ and for Islamic banks it rises to $16.3 \%$. As a result, the hypothesis is accepted for ROW that the performance of Islamic banks is equivalent to conventional banks.

Yield on earning assets ratio of both Islamic banks and conventional banks are significantly different for last five years. Table 4.1 shows that Islamic banks yield on earning assets ratio reduced in 2006, although there is a improvement in 2005 as YOEA increases to 3.8\%. Meanwhile for conventional banks, the ratio is also reduced in 2006. At the 5\% confidence level, the hypothesis is rejected, therefore YOEA is significantly different. 
In last five years, cost of Funds ratio of Islamic banks is almost identical to that of conventional banks. From Table 4.1 we can see that cost of funds of both Islamic and conventional banks is almost same, although in 2003 the cost of funds ratio of Islamic banks is higher with $2.5 \%$ to that of $1.9 \%$ for conventional banks. So, at the confidence level of 5\%, we can say that cost of funds of both Islamic and conventional banks does not significantly differ. Net Profit Margin ratios of Islamic banks are higher than that of conventional banks in years from 2002 to 2005. (See Table 4.1). But in 2006, net profit margin ratio of Islamic banks drastically goes down; mainly due to the fact that capital gain on sale of investment of Albaraka banks goes down from 290,729 to 1,775 (See Annual Report 2006). So overall, at the confidence level of $5 \%$ the net profit margin ratio is rejected and thus we conclude that net profit margin ratio of two banks is significantly differ.

Spread is the difference between Yield on earning assets and Cost of funds. As we can see in Table 4.1, spread ratio of Islamic banks are higher than that of conventional banks. Therefore, the hypothesis is accepted that Islamic banks performance is equivalent to Conventional banks.

\subsection{Liquidity Ratios}

Comparing liquidity ratio of the Islamic banking and conventional banking reveals that Islamic banking Cash to Deposit ratio is very high which means that they have high deposits and they are not taking full advantage from that, are just holding funds and not advancing them as loan. This also shows that Islamic banking is lagging in the product sector as compared to conventional banking; it could be any reason from high interest rate to unsatisfactory services. Immediate recommendation for Islamic banks arises that they have to tailor and match their products with conventional banking in order to beat the conventional banks. Another factor could be management deficiency of managing funds that have to be solved in order to get the full fruits of the future prospects of Islamic banking (See Table 4.1).

Advances to deposits ratio of both Islamic banks and conventional banks are decreasing in 2006 with respect to 2005. There is a Statutory Reserve Requirement SRR for every bank to keep a reserve amount of deposits as per requirement of State Bank policy. Conventional and Islamic banks have a different SRR requirement that's why there is a great difference between both banks Advances to deposits ratio. Therefore the hypothesis is rejected for both banks and they significantly differ with each other. 


\subsection{Business Development Ratios}

The growth ratios are calculated horizontally from year to year. In this we have taken 2002 as a base year to compare the growth of Islamic banks and conventional banks in terms of total assets, deposits, advances and earnings.

Total Assets growth ratios of both Islamic and conventional banks are increasing from 2002. Therefore at the 5\% confidence level, the hypothesis is accepted $\backslash$ and it is concluded that the total assets growth ratio of both banks do not significantly differs. Deposits growth ratio of both Islamic banks and conventional banks are increasing in last four years, which shows positive trend that more customers are depositing their money in their respective banks. As both Islamic and Conventional banking system ratios are increasing we can conclude that both are not statistically significant at the 5\% interval. Advances growth ratio shows that increase of financing of both Islamic banks and Conventional banks are increasing in relative to base year 2002. So, the difference between the average means for Islamic and Conventional banks is statistically significant at the 5\% confidence interval. Therefore, it is concluded that the hypothesis that the 'Islamic banks performance is identical with conventional banks' is accepted.

Earning or net profit of both Islamic and Conventional banks are increasing relative to the base year of 2002. Table 4.1 summarizes that for Islamic banks the earnings shows a improvement up to 2005 that is $212 \%$ from $80.0 \%$ in 2003, but in 2006 it slightly goes down to $185 \%$. Meanwhile the earnings of conventional banks shows a negative sign in 2003, which is because Mybank net profit is negative in the year 2003 that is 20,139 . The reasons for such a high growth in respective years of 2004-2006 are because My Bank net profits show a great increase from 3,657 in 2002 to 492,888 in 2006 (See Annual Reports). As both banks earnings are increasing, we can conclude that at the significant level of 5\% both Islamic and Conventional banks not significantly differ and therefore we accept the hypothesis.

\subsection{Efficiency Ratios}

Assets utilization ratios indicate those both Islamic and Conventional banks ratios are increasing, which shows that both banks are effectively and efficiently using their assets to generate sales more productively. Therefore both Islamic banks and conventional banks curve are parallel to each other, so at the confidence level of 5\% the asset utilization ratio does not significantly differ with each other. Operating Efficiency ratio of Islamic banks as shown in Table 4.1 indicates that there is an increase in the ratio from $71.1 \%$ in 2002 to $494 \%$ in 2006. This trend shows that Islamic banks expenses are high and earnings 
are low, especially in 2006. This happens because in 2006 Meezan Bank pays $1,027,767$ total operating expenses which are more than 718,866 in 2005 . Moreover, in conventional the trend is also similar that there is an increase in operating efficiency ratio, but in the year 2006 the operating efficiency ratio decreases to $121 \%$ from $207 \%$ in 2005 . There fore, overall at the significance level of $5 \%$, both banks ratio doesn't significantly differ with each other.

\subsection{Risk and Solvency Ratios}

Debt to total assets ratio of Islamic banks as shown in Table 4.1 is increasing from $81.3 \%$ in 2002 to $89.1 \%$ in 2006 . While for conventional banks the debts to total assets ratios are decreasing from $90.6 \%$ in 2002 to $86.5 \%$ in 2006 . Therefore we can conclude at confidence level of $5 \%$ that the hypothesis is rejected and thus the debts to total assets ratio significantly differ.

Equity Multiplier ratio of cumulative average of Islamic banks shows that is increasing every year that is from $563 \%$ in 2002 to $918 \%$ in 2006 . For conventional banks cumulative average, we can see that the equity multiplier ratio is decreasing from $1084 \%$ in 2002 to $892 \%$ in 2006, see Table 4.1. After analyzing last five years Islamic banks average mean is $757 \%$ while it was $1104 \%$ for conventional banks. Therefore, it is concluded that Islamic banks need to increase their solvency by increasing debt compared to equity. The two means statistically differ.

\section{Final Remarks}

The analysts use different approaches in analyzing the bank. However, the analytical tools used in this project to assess the financial condition and profitability of conventional and Islamic banks are the FINANCIAL RATIOS. After calculating financial ratios separately for all banks, the results are aggregated for conventional and Islamic groups respectively. Finally, a rigorous t-test is conducted to check if aggregate results of both groups complement each other or not. Islamic banks now have developed enough since they have been in the context for so many years. Thus, not to much surprise that 10 out of 16 ratio indicators of performance of both types of banks lead to accept the hypothesis that Islamic banks have performed almost to the level that of Conventional Banks.

But, it must be clearly noted that remaining 6 ratio indicators which reject the null hypothesis need to be studied in depth with respect to their importance before reaching any ultimate conclusion. Thus, there is a need to determine the most important indicators which really are very crucial in determining ultimate performance of banks and their peer groups. In this regard, it must be noted that the ratio indicators which lead to reject the null hypothesis are the most important or crucial in determining the 
bank's performance. Many ratios which accepted the null hypothesis belongs to the growth ratios which just enlighten the growth in certain items over period of time. These types of ratios do not separately determine actual performance or efficiency of a bank. Rather, these are only supplemental information to main stream ratios like Net Profit Margin, Risk \& Solvency Ratios, and Yield on Earning Assets, etc.

It is obvious that most important ratios lead to reject our basic hypothesis and thus we cannot justify completely that the Performance of Islamic banks is equal to Performance of Conventional Banks. Rather, there are some items which are hiding the actual performance of Islamic banks. Thus, the results should be extracted after adjusting these indicators and emphasizing main and crucial ones.

Researchers see that both groups generate different yield on their earning assets which is a thing for concern. This ratio also indicates very insight view of bank's revenue (interest) generating capability or by average earning assets. Thus, it reflects to Islamic banks don't earn enough income on main earning assets compared to conventional banks. As, we see ROA \& ROE are almost similar for both groups. Thus, we can conclude from this that returns earned on overall assets may be similar for both but if we only consider earning assets then it is different and yet Islamic banks have not been able to generate that to the level of other banks. Moreover, we see that Asset Utilization and Operating Efficiency ratios indicate that Islamic banks also utilize its assets as efficiently as other banks do. But, yield on earning assets has shown both types of banks have not been at equal level if only earning assets are considered which a concern for Islamic banks is even after such a long time.

Further, it is seen that growth in total assets, deposits, advances and earnings for both Islamic and conventional banks has been almost equal. But, again to our surprise we observe that important indicators of liquidity of any bank don't confirm to this trend. The ratios i.e. Cash-to-Deposits, Net Profit Margin and very important Advances-toDeposits lead to reject the null hypothesis that the performance of both types of banks is equal. Advances to Deposits ratio indicates that Islamic banks have not been able to generate as much advances compared to deposits available to them. This reflects conventional banks have been more efficiently generating more and more advances out of same number of deposits. This can confirm our earlier prediction that Islamic banks on aggregate have not been able to focus on main earning assets rather on non-operating or non-earning assets. That is why yield on earning assets is also on average low for Islamic banks.

Similarly, Cash-to-Deposits is also not maintained to the level of conventional banks which indicates Islamic banks don't maintain enough cash related to the level of their deposits. They have not been able to maintain it considering that they have also not been able to give away advances out of that. Thus, it may reflect to that Islamic banks on average may be spending more on non-operating expenses or may be they have not been able to control all types of expenses given that cash and advances are not maintained to their deposits as compared to conventional banks. 
Net Profit Margin for Islamic banks has also been low as compared to conventional banks given that ROE \& ROA for both types of banks are almost same. It reflects that Islamic banks have not been able to generate enough profit compared to other banks given the same revenues for both groups. It may refer to that Islamic banks have not been able to control and minimize their expenses or may be their non-operating expenses are making the impact.

Finally, the solvency position and riskiness of Islamic banks has appeared to be issue as compared to conventional banks. Their Debt-to-Asset ratio and Equity Multiplier indicates that Islamic banks have less proportion to debt related to assets as compared to conventional banks. This makes Islamic banks more risky compared to conventional banks because a bank needs to have more and more debt and less equity to earn enough on earning assets and to increase total earning assets. This also saves owners to put les and less money on risk.

\section{5: PRODUCT SERVICE ANALYSIS}

This section deals with product and service analysis between Islamic and Conventional banks in Pakistan. The section basically compares the products and servicesof Islamic and Conventional banks in terms of deposit, financing and service.

Banks perform two major functions which are borrowing and lending of money. Bank borrows by taking deposits from its customer and lends to those who are in need of money. Banks offer different types of products and services for the benefit of its customer. Different types of deposits accounts are offered to provide higher return with the best possible service. Bank uses this deposit to lend money to its customer. It offers different financing schemes, such as personal finance, car finance and home finance. In recent years, banks make their services convenient through electronic banking. Recent growth of e-banking includes ATM Cards, 8 to 8 banking service, Internet banking, Credit cards (for conventional) and so on. Product and service analysis of both Islamic and Conventional banks are divided into three parts, as explained below:

\subsection{Deposits}

One of the major functions of banking is to borrow money. Both Islamic and Conventional banks use different types of deposit accounts to facilitate their customers. There are number of deposit accounts, the most prominent ones are current account and saving account. In current account, there is no interest or profit for the customer, while for saving there is a fixed amount of interest for conventional customer and profit loss sharing for Islamic customer. Moreover, Banks also offer different term deposit certificate accounts to benefit the customer in terms of different maturity period. These term deposit are offered to those customers who have the intention of retaining their savings 


$\overline{\text { Business Review - Volume } 5 \text { Number } 1}$ January - June 2010

for a fixed period and therefore to earn a higher return. In the next section we will analyze different deposits and certificate accounts of Meezan Bank, Albaraka Bank, Soneri Bank and My Bank.

\subsubsection{Deposit Accounts}

Banks use different types of saving deposit accounts to cater the need of their customers. Table 5.1 shows the deposits account use by Meezan Bank, Albaraka Bank, Soneri Bank and Mybank.

Table 5.1

Deposits Account

\begin{tabular}{|c|c|}
\hline Meezan Bank & Soneri Bank \\
\hline - Current Account & - Current Account \\
\hline - Rupee Savings Account & - Profit \& Loss Savings Account \\
\hline - Karobari Munafa Account & - PLS Soneri Savings Account \\
\hline \multicolumn{2}{|l|}{ - Meezan Bachat Account } \\
\hline Albaraka Bank & Mybank Limited \\
\hline - Current Account & - Current Account \\
\hline - Rupee Savings Account & - PLS Saving Deposit Account \\
\hline - Khazana Account & - Business Premium Account \\
\hline - Inventive Account & - Basic Banking Account \\
\hline
\end{tabular}

The following Tables (Table 5.2 and 5.3) compare the rate or profit between Meezan Bank's Savings Account with Soneri Bank's Savings Account. Soneri Bank gave fixed amount of return, while Meezan Bank works on the basis of profit loss sharing. Therefore, we have taken averages of last one-year profit rates of Meezan Bank. After analyzing the below table, it is concluded that for small amount of Investors, Soneri Bank would be an ideal choice because the return that Soneri Saving Account offers much higher than that of Meezan Bank. 
Table 5.2

Meezan Saving Account

\begin{tabular}{|c|c|}
\hline Amount & Average \\
\hline 10K-99.9K & $1.9 \%$ \\
\hline $100 \mathrm{~K}-9999 \mathrm{~K}$ & $2.2 \%$ \\
\hline $1 \mathrm{M}-499 \mathrm{M}$ & $25 \%$ \\
\hline $5 \mathrm{M}-9.99 \mathrm{M}$ & $2.8 \%$ \\
\hline $10 \mathrm{M}-4999 \mathrm{M}$ & $2.9 \%$ \\
\hline $50 \mathrm{M}-9999 \mathrm{M}$ & $3.0 \%$ \\
\hline $100 \mathrm{Mm}+$ & $3.3 \%$ \\
\hline
\end{tabular}

Table 5.3

Soneri Saving Account

\begin{tabular}{|c|c|}
\hline Amount & Fixed Rate \\
\hline Upto Rs. 25K & $1.0 \%$ \\
\hline $25 \mathrm{~K}-1 \mathrm{M}$ & $\mathbf{4 . 0 \%}$ \\
\hline 1M-10M & $\mathbf{5 . 0 \%}$ \\
\hline $10 \mathrm{M}+$ & $\mathbf{6 . 0 \%}$ \\
\hline
\end{tabular}

Meezan Bank also offers a Meezan Bachat Account (MBA), see Table 5.4. It is a unique rupee savings account specifically tailored for Business Corporations, Entrepreneurs and Individuals. MBA combines a high rate of monthly profit, flexibility of withdrawal and convenience, all in one. The special tiering structure ensures a higher profit on higher deposits. Therefore, it is concluded that for large amount of investor, it is beneficial to invest in Meezan Bachat account to earn higher profit.

Table 5.4

Meezan Bachat Account

\begin{tabular}{|c|c|}
\hline Amount & Average \\
\hline $1-24.99 \mathrm{~K}$ & $0.2 \%$ \\
\hline $25 \mathrm{~K}-19999 \mathrm{~K}$ & $5.6 \%$ \\
\hline $200 \mathrm{~K}-499.99 \mathrm{~K}$ & $6.1 \%$ \\
\hline $500 \mathrm{~K}-1 \mathrm{M}$ & $7.0 \%$ \\
\hline
\end{tabular}

Now we look at the rate of return between Albaraka Khazana Accounts and Mybank PLS Saving Deposit Account. Table 5.5 and 5.6 shows that My Bank is giving better rates for small investors, while Albaraka Bank giving up to 9\% profit return, if the amount is above 500 Million. Investors with large amount of money can invest in Albaraka bank, in order to earn good rate of return. 
Table 5.5

Albaraka Khazana Account

\begin{tabular}{|c|c|}
\hline Amount & Average \\
\hline $250 \mathrm{~K}-4,999 \mathrm{~K}$ & $4.6 \%$ \\
\hline $5,000 \mathrm{~K}-9,999 \mathrm{~K}$ & $4.7 \%$ \\
\hline $10,000 \mathrm{~K}-24,999 \mathrm{~K}$ & $5.0 \%$ \\
\hline $25,000 \mathrm{~K}-49,999 \mathrm{~K}$ & $5.1 \%$ \\
\hline $50,000 \mathrm{~K}-99,999 \mathrm{~K}$ & $5.8 \%$ \\
\hline $100,000 \mathrm{~K}-499,999 \mathrm{~K}$ & $6.4 \%$ \\
\hline $500 \mathrm{M}+$ & $9.0 \%$ \\
\hline
\end{tabular}

Table 5.6

My Bank PLS Saving Account

\begin{tabular}{|c|c|}
\hline Amount & Fixed Rate \\
\hline Up to Rs. 5000 & $2.0 \%$ \\
\hline $5001-50,000$ & $4.0 \%$ \\
\hline $50,001-100,000$ & $4.5 \%$ \\
\hline $100,001+$ & $5.0 \%$ \\
\hline
\end{tabular}

From the above tables it is concluded that both Conventional banks are providing better rate of returns for small investors. Meanwhile, Islamic banks are providing higher profit return for large deposits.

\subsubsection{Term Deposit Accounts}

Banks use different types of term deposit account or deposits certificates to cater the need of their customers. Certificate are offered by banks to individuals (in single or joint names), minors (to be operated by the guardian), Charitable Institutions, Provident Fund and other funds of benevolent nature local bodies, Autonomous Corporations, Limited Companies, Firms, Associations, Educational Institutions etc who have the intention of retaining their savings for a fixed period thereby earning a higher rate of profit than the normal deposit account. Profit or returns of certificate account are offered at the time of maturity and Pre-matured encashment is allowed without any penalty however profit will be less than originally contracted. For Islamic banks Meezan Bank certificates account include; certificate of Islamic Investment, Monthly Mudarbah Certificate, Meezan Amadan Certificate and Meezan Providence Certificate, meanwhile for Albaraka bank it includes Term Deposits, AMI Account. For conventional, Soneri bank includes PLS Term Deposits, Soneri Sarmaya Certificates and Soneri Savings Certificate, meanwhile for Mybank it includes Fixed Term Deposits Scheme and Term Deposit Regular.

From Table 5.7 and 5.8, we can see that Meezan Bank's Certificate of Islamic Investment is providing better return as compared to Soneri Bank's Soneri Sarmaya Certificate in terms of amount invested for 1 year to 4 year but for 5-year investment Soneri Sarmaya Certificate return is much better. 
Table 5.7

Meezan Bank

Certificate of Islamic Irvestment

\begin{tabular}{|c|c|}
\hline Term or Tenures & Average \\
\hline 3 Months & $5.20 \%$ \\
\hline 6 Months & $5.70 \%$ \\
\hline 1 Year & $6.80 \%$ \\
\hline 2 Years & $7.30 \%$ \\
\hline 3 Years & $8.20 \%$ \\
\hline 5 Years & $8.90 \%$ \\
\hline
\end{tabular}

* Minimum Amount 50,000
Table 5.8

Soneri Bank Soneri Sarmaya Certificate

\begin{tabular}{|c|c|}
\hline Term or Tenures & Rate \\
\hline 1 Year & $\mathbf{6 . 0 0} \%$ \\
\hline 2 Years & $\mathbf{6 . 5 0} \%$ \\
\hline 3 Years & $7.00 \%$ \\
\hline 4 Years & $\mathbf{8 . 0 0} \%$ \\
\hline 5 Years & $\mathbf{9 . 5 0} \%$ \\
\hline 6 Years & $\mathbf{1 1 . 5 0} \%$ \\
\hline
\end{tabular}

* Minimum Amount 50,000

Meanwhile, Mybank's Term Deposit Regular is providing better return than Albaraka's Term Deposit Certificates (See Table 5.9 and 5.10). Therefore, we conclude that both Islamic and conventional banks are providing good return in terms of deposit certificates.

Table 5.9

Albaraka Bank Term Deposit

\begin{tabular}{|c|c|}
\hline Term or Tenures & Average \\
\hline 1 Month & $3.54 \%$ \\
\hline 3 Months & $6.05 \%$ \\
\hline 6 Months & $6.19 \%$ \\
\hline 1 Year & $6.34 \%$ \\
\hline 2 Years & $7.00 \%$ \\
\hline 3 Years & $\mathbf{8 . 3 8} \%$ \\
\hline 5 Years & $9.25 \%$ \\
\hline
\end{tabular}

* Minimum Amount 50,000
Table 5.10

MyBank Term Deposit Regular

\begin{tabular}{|c|c|}
\hline Term or Tenures & Rate \\
\hline 1 Month & $\mathbf{6 . 0 0} \%$ \\
\hline 3 Months & $7.00 \%$ \\
\hline 6 Months & $\mathbf{8 . 0 0} \%$ \\
\hline 1 Year & $\mathbf{1 0 . 5 0} \%$ \\
\hline 2 Years & $\mathbf{1 0 . 7 5} \%$ \\
\hline 3 Years & $\mathbf{1 1 . 0 0} \%$ \\
\hline
\end{tabular}

* Minimum Amount 50,000

\subsection{Financing}

Banks offer different financing products for their customers. Some of them are personal finance, Home Finance and Car Finance. Islamic banks provide Home and Car Financing with totally RIBA-FREE and according to the Shariah rule. However, Islamic banks still do not provide RIBA-FREE Personal loan. In the next two sections we will look at the Home and Car Financing schemes of Islamic and Conventional banks. 


\subsubsection{Home Financing}

Conventional and Islamic banks both offers home financing to cater the needs of their customers. In the next section Meezan Bank home financing is compare with Soneri Bank while Albaraka Bank is compared with Mybank limited.

\section{Meezan Easy Home}

Meezan Bank is the first Islamic bank to provide the first complete Islamic home finance facility in Pakistan. With Easy Home the customer participates with Meezan Bank in a joint ownership of the property, where the Bank will provide a certain amount of financing (usually up to $85 \%$ ). Customer agrees to pay a monthly amount, and the monthly payment reduces regularly as your share in the property grows. Meezan Easy Home deals with buying a home, building a home and replacing or renovating a home. Table 5.11 shows the finances and the tenure of Meezan Easy Home.

Table 5.11

Meezan Easy Home Financing

\begin{tabular}{|l|l|}
\hline Building a Home & $\begin{array}{l}\text { - Financing up to } 85 \% \text { of the appraised value of the home or up } \\
\text { to a value of } 40 \text { Million }\end{array}$ \\
\hline Building a Home & Financing Tenure up to 20 Years \\
\hline Renovating a Home & $\begin{array}{l}\text { - Financing up to } 70 \% \text { of the appraised value of the home or up } \\
\text { to a value of } 40 \text { Million }\end{array}$ \\
& $\begin{array}{l}\text { - Financing Tenure up to } 20 \text { Years } \\
\text { - Financing up to } 30 \% \text { of the appraised value }\end{array}$ \\
\hline
\end{tabular}

\section{Soneri Ghar Finance}

Soneri Ghar Finance offers a maximum finance of Rs. 5 million and a convenient repayment period of up to 10 years. See Table 5.12 for the details of Soneri Ghar Finance. 
Table 5.12

Soneri Ghar Finance

\begin{tabular}{|c|c|}
\hline $\begin{array}{l}\text { Financing Amount and } \\
\text { Payment Period }\end{array}$ & $\begin{array}{l}\text { - Purchase/Construction of residential property up to Rs. } 5 \text { Million } \\
\text { with tenure up to } 10 \text { years } \\
\text { - Extension/Renovation on own property up to Rs. } 2 \text { Million with } \\
\text { tenure up to } 7 \text { years }\end{array}$ \\
\hline $\begin{array}{l}\text { Mark up rates and } \\
\text { Fee, Legal Charges, Valuations }\end{array}$ & $\begin{array}{l}\text { - Floating Mark up rate @ } 4.5 \% \text { above prevailing SBP Discount } \\
\text { Rate (Minimum 14\%) } \\
\text { - Processing fee: Rs. } 2500 / \text { - or } 0.50 \% \text { of the finance amount } \\
\text { which ever is higher. } \\
\text { - Legal/valuation charges Rs.3000/-. }\end{array}$ \\
\hline
\end{tabular}

\section{Albaraka Home Finance}

Albaraka's 'Maskan' home finance scheme deals with purchase of house/flat, construction of house, purchase of plot \& construction, renovation of house/flat and asset transfer facilities. Some features of Albaraka home finance scheme are: Strictly Shariah Compliant; Minimum Processing charges; Up to $80 \%$ of Bank's participation; Low rental rates; Fixed and floating rate options; Repayment tenure from 3-20 years; Financing up to Rs. 20 Million; Bank Shares in Insurance and property tax; and Coapplicant option.

\section{Mybank Home Finance}

Mybank Home Finance scheme 'my Sahoolat' offers financial assistance in building a home/apartment/land, renovating a business, and redecorating a home. Some Features of 'My Sahoolat' home finance scheme are: Annualized Mark-up rate 15.5\%; Maximum Limit of Rs. 10 Million; Life Insurance coverage; Quickest Processing time.

After comparing both Meezan bank with Soneri bank and Albaraka bank with Mybank, it is quiet obvious that Islamic banks are providing much better home financial assistance than conventional banks. Meezan bank offers 40 Million financing up to 20 years, meanwhile Soneri bank provide financing up to 5 Million up to 10 years. Albaraka bank is also providing financing up to Rs 20 Million with tenure up to 20 years, meanwhile Mybank 'my Sahoolat' scheme offers maximum limit of 10 Million financing. Therefore, we conclude that both Islamic banks are better providers of financing assistance for home than conventional banks. 


\subsubsection{Car Financing}

To compare the Conventional and Islamic banks car financing, we will here focus on Meezan Car Ijarah, Soneri Car Finance, Albaraka Car Ijarah and Mybank Auto Financing.

\section{Meezan Car Ijarah}

Meezan Bank's Car Ijarah is a car rental agreement, under which the Bank purchases the car and rents it out to the customer for a period of 3 to 5 years, agreed at the time of the contract. Upon completion of the lease period the customer gets the ownership of the car against his initial security deposit. Just like a normal rent agreement Meezan Bank takes a security Deposit ranging from a minimum of $15 \%$ to a maximum of $50 \%$. The actual requirement of Security deposit varies for different type of vehicle (that is new, old or imported etc). Meezan Car Ijarah is available for locally assembled as well as imported cars; moreover used cars are also financed.

Meezan Bank being the owner of the Car is responsible for Insurance of the car and for payment of insurance premium. In this regard, Meezan Bank insures Car from Pak Kuwait Takaful Co (PKTC) the Islamic mode of Insurance (Takaful) and pays Takaful premium as part of its ownership expense.

\section{Soneri Car Finance}

Soneri Car Financing scheme gives a loan to the customer for purchase of car and charges interest on it. See Table 5.13 for features of Soneri Car Finance.

Table 5.13

Soneri Car Finance Features

\begin{tabular}{|c|c|}
\hline $\begin{array}{l}\text { Financing Amount and } \\
\text { Payment Period }\end{array}$ & $\begin{array}{l}\text { - } \text { Rs. } 1 \text { Million (Cars up to } 2300 \text { C.C) } \\
\text { - } \\
\text { - } \\
\text { Max. } 2 \text { Million (Above } 2300 \text { C.C) } \\
\text { Maximum period of financing are } 5 \text { Years }\end{array}$ \\
\hline Down Payment & $\begin{array}{l}\text { - On Finance of up to Rs. } 1 \text { Million (Minimum 15\% of Car Price) } \\
\text { - One Finance exceeding Rs } 1 \text { Million but not more than } 2 \text { Million } \\
\text { (Minimum 20\% of Car Price) }\end{array}$ \\
\hline Mark Up & $\begin{array}{l}\text { - } 14 \% \text { for up to } 3 \text { years tenure } \\
\text { - } 15 \% \text { over } 3 \text { year's tenure, (Maximum up to } 5 \text { years) }\end{array}$ \\
\hline
\end{tabular}




\section{Albaraka Car Ijarah}

Albaraka's car Ijarah offers financing up to the maximum limit of 1 Million. Albaraka's car Ijarah is strictly compliant to Islamic Shariah. The facility has an early adjustment option in which asset can be purchased by making payments at the pre determined amount given in the undertaking to purchase the leased asset. Provisional rental schedule are provided to the customer at the time of booking of the asset and the payment will be made on the basis of the schedule. Features of Albaraka's car Ijarah are: Maximum amount Rs. 1 Million; Tenure of financing 3 and 5 years; Brand new unregistered car available; Strictly compliant to Islamic Shariah; $10 \%$ of the value of the car to be provided as security deposit; One time processing and documentation charges Rs. 3,000.

\section{My-bank Auto Financing}

Mybank Auto financing offers a wide range of vehicle with an affordable price. Luxurious car, motorbike or buses for crew are available. Features of Mybank auto financing are: Lowest Insurance premium; Tracker device is also financed; Tenure 1-3 years with annualized mark up rate $15 \%$; Tenure $4-5$ years with annualized mark up rate $15.5 \%$.

After comparing both Meezan bank with Soneri bank and Albaraka bank with Mybank, we conclude that both conventional banks and Islamic banks are providing similar types of car or auto financing to their customers. Albaraka is providing $10 \%$ security deposits of the value of the car, which is better than Meezan, Soneri and Mybank. Therefore, it is concluded that both conventional and Islamic banks are providing better car financing services for its customer.

\subsection{Services}

Banks offer wide range of service to its customers. In this section, we will look different services that are provided by Meezan Bank, Soneri Bank, Albaraka Bank and Mybank. 
Table 5.14

Banking Services

\begin{tabular}{|c|c|c|c|c|}
\hline Services & Meezan & Soneri & Albaraka & MyBank \\
\hline Online Banking & $\square$ & $\square$ & $\square$ & $\square$ \\
\hline ATM Card & $\sqrt{4}$ & $\square$ & $\sqrt{9}$ & 西 \\
\hline Debit Card & 四 & 四 & 田 & 四 \\
\hline 8 to 8 Banking Service & 四 & & & \\
\hline Ladies Banking & v & & & \\
\hline Telephone Banking & & $\square$ & 四 & $\square$ \\
\hline Internet Banking & v & $\square$ & & v \\
\hline Mobile Banking & v & & & \\
\hline SMS Alert & v & & & \\
\hline Utility Bills & v & 四 & $\square$ & v \\
\hline Lockers & $\sqrt{9}$ & 西 & 录 & $\sqrt{9}$ \\
\hline Agricultural Scheme & & & & 田 \\
\hline
\end{tabular}

\section{6: CUSTOMER PERSPECTIVE}

This chapter deals with the customer's perspective about Islamic banking and Conventional banking. This chapter consists of findings and interpretations of survey analysis which are conducted between different banks in Karachi.

In this survey different age group are selected with majority lying between 20 to 35 age brackets. This survey is conduced mainly by students, businessmen and bankers. The findings and interpretation of survey analysis that are conducted between different customers of both Islamic and Conventional banks are explained below with different factors and variables.

The survey is conducted among various customers of both Islamic and conventional banks are done on the basis of customers having more than 2 accounts in a bank. The survey identifies that majority of customers having a bank account in Habib Bank, Bank Alfalah, Soneri Bank and Standard Chartered Bank. Figure 6.1 describes that $20 \%$ of the customers have a bank account in Habib Bank, $17 \%$ having account in Bank Alfalah, 15\% and 14\% having account in Soneri and Standard Chartered Bank respectively. Customers also have a bank account in Union Bank Limited, Allied Bank Limited and Habib Metropolitan which lies in 'Other' category. Figure 6.1 also clarifies that majority of the customers having bank account in conventional banks 
rather than Islamic banks. $12 \%$ of the customers having bank account in Meezan banks which is the highest ratio among the Islamic banks.

Figure 6.1: Bank Accounts

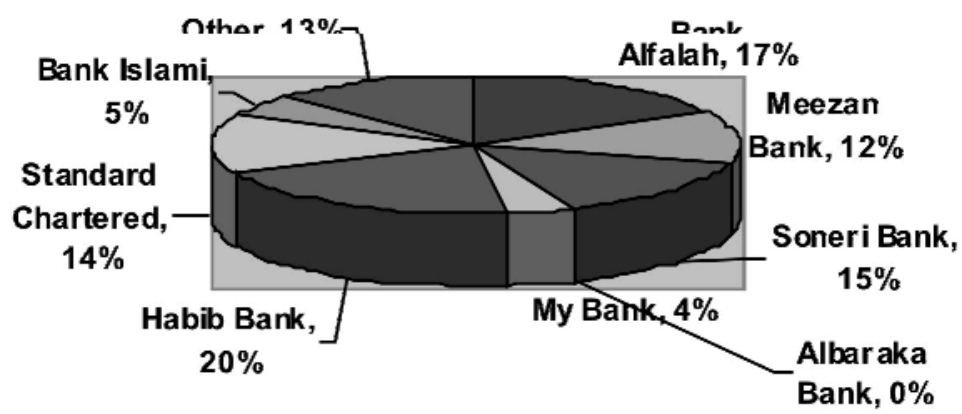

In the sample of hundred customers, $64 \%$ prefer conventional banking over Islamic banking that is $36 \%$ (See Table 6.1). The reasons for the preference of conventional banking over Islamic banks are because they offer better service and variety of products than Islamic banks. As figure out in the below cross tabulation chart, it is concluded that according to the 100 sample response, both banks customers prefer the services as their best priority among all others. As far as Islamic banks are concerned majority of the customers prefer Islamic banking because it is Islamically legal. Twenty nine responses that are $51 \%$ of the total response prefer Islamic banking because it is Islamically legal and out of which $34 \%$ have studied the literature on Islamic banking while $17 \%$ haven't studied literature on Islamic banking. This clarifies that customers prefer Islamic banking because it is Islamically legal not because of Islamic banks performance.

TABLE 6.1: CROSS TABULATION

\begin{tabular}{|l|c|c|c|c|c|c|}
\hline & \multicolumn{2}{|c|}{ Valid } & \multicolumn{2}{c|}{ Missing } & \multicolumn{2}{c|}{ Total } \\
\hline & N & Percent & N & Percent & N & Percent \\
\hline Q1 * Products & 29 & $29.0 \%$ & 71 & $71.0 \%$ & 100 & $100.0 \%$ \\
Q1 * Services & 62 & $62.0 \%$ & 38 & $38.0 \%$ & 100 & $100.0 \%$ \\
Q1 * Islamically & 29 & $29.0 \%$ & 71 & $71.0 \%$ & 100 & $100.0 \%$ \\
Q1 * Return & 20 & $20.0 \%$ & 80 & $80.0 \%$ & 100 & $100.0 \%$ \\
Q1 * Other reasons & 2 & $2.0 \%$ & 98 & $98.0 \%$ & 100 & $100.0 \%$ \\
\hline
\end{tabular}


Table 6.2 below clarifies that both Islamic banks and conventional banks customers are satisfied by the number of branches of their banks. $86 \%$ of Islamic and $80 \%$ of conventional customers is satisfied by the number of branches of their banks. Although both banks customers are satisfied by the number of branches but still various customers gave their remarks to operate the branches in the interior city.

TABLE 6.2

\begin{tabular}{|c|c|c|c|c|}
\hline \multicolumn{5}{|c|}{ Q1 * Q6 Cross tabulation } \\
\hline & & & No. of Branch & \\
\hline \multirow{3}{*}{ Q1 } & & Satisfied & Not Satisfied & Total \\
\hline & Islamic & 31 & 5 & 36 \\
\hline & Conven. & 51 & 13 & 64 \\
\hline \multicolumn{2}{|c|}{ Total } & 82 & 18 & 100 \\
\hline
\end{tabular}

Descriptive statistics are also applied in both Islamic and Conventional Banks. Descriptive statistics of Islamic banks shows that in Islamic banks majority of the customers prefer Meezan Bank as their best choice for banking. The next best priorities are Dubai Islamic, Bank Islamic, Emirates Islamic bank and Bank Albaraka. Meezan Bank as the largest Islamic bank in Pakistan covering more than 100 branches in the span of only 5 years is preferred by majority of the Islamic customers.

Meanwhile for conventional banks, majority of customers prefer Habib bank as their best choice to conduct banking. The next best priorities are Bank Alfalah, Standard Chartered, Soneri Bank and Mybank Limited. Habib bank is the first bank in Pakistan that established operations in 1947. The major reason for the preference of Habib bank is its large branch network.

The conclusion that we get from this survey is that after such an enormous growth in Islamic banking still customers prefer conventional banks to perform their banking and majority of customers still thinks that Islamic banking has some flaws over their Islamic in nature and gave their remarks against the Islamic banking and supposed that there is no such difference in nature of the transaction. Although both banks customers are satisfied with the service, number of branches and the profits rates. Therefore, it is concluded that conventional banks are preferred over Islamic banks.

\section{7: CONCLUSION}

The comparison between Islamic banks and conventional banks are done to identify which banking system is superior according to their performance. The financial 
analysis comparison shows that the financial performance of Islamic bank is not exactly superiors to that of conventional banks. Although 10 ratios out of 16 are accepting the hypothesis that both banks performances are identical but still the 6 ratios that are rejected are the most important one in comparing financial health of any bank. The six ratios that are rejected are yield on earning assets, net profit margin, cash to deposit, advances to deposit, debt to total assets and equity multiplier. The major drawback of Islamic banks that is their deposits is increasing but they are not taking full advantage of it and just holding their funds. In addition Islamic banks are not using its assets more effectively and efficiently as conventional banks. Therefore it is concluded that Islamic banks has to take the advantage of these drawbacks in order to capture the market.

The comparison of product and services between Islamic and conventional banks are divided into deposits account, financing and services that both banks offered to their customers. Deposits and certificates accounts of both Islamic and conventional banks shows that both banks are offering good return in terms of the amount that the customer are investing. For deposits account, it indicates that for small amount of investors conventional banks are better and for large amount of investors Islamic banks return are much better. For certificates account, it indicates that conventional banks are providing better return than Islamic banks. Islamic banks are providing much better home financial assistance then conventional banks whereas Islamic banks are offering higher amount then conventional banks. They are also financing up to 20 years. Therefore, we conclude that both Islamic banks are much better to provide financing assistance for home then conventional banks. Meanwhile for car financing, it is concluded that both Islamic and conventional banks are providing similar types of car financing to its customers. Services of Islamic banks are up to the level of conventional banks. Meezan bank is the largest Islamic bank in Pakistan covering more than 100 branches offers 8 to 8 banking service that is first in Pakistan. Like Meezan bank other Islamic banks should grow further in terms of services and branch network to compete with conventional banks and other Islamic banks.

For identifying the customer perspective about Islamic and conventional banking, a survey was conducted among customers of both banks. After conducting analyses of the survey, majority of the customers still prefer conventional banks for banking. Islamic banks are preferred among those who think that it is Islamically legal and not because of their performance via products and services. Meezan bank being the largest Islamic bank in Pakistan is preferred by majority of the customers. Meanwhile, for conventional banks Habib banks is preferred among others.

This research study is conducted to identify which banking system is going superior with each other. After analyzing the research study with respect to financial analysis, product service comparison and customer perspective. It is concluded that Islamic banks although are growing compare to last few years but still they have to do 
a lot in order to capture the market in Pakistan. Meanwhile for other Islamic countries like Malaysia, UAE and Bahrain, lot of research study are done and there Islamic banks are growing at much faster rate than Pakistan. (Anwar, 2000) conducted a research in Malaysia, and (Kader, 2005) conducted research in UAE conclude that Islamic banks are growing much rapidly then conventional banks. They said that the rapid growth in Islamic banking is likely to be associated with the attributed of the Islamic profit and loss sharing banking paradigm. Therefore Islamic banking in Pakistan has to do a lot in order to compete with conventional banks. This research study also identifies several recommendations for Conventional banks and Islamic banks, which are given below.

\section{Recommendations}

Following are some recommendations of banking in general and Islamic banking in specific:

- Islamic banks must focus more on their main earning assets to utilize them more efficiently along with any non-operating income they have been generating. It is because non-operating income inflates total profitability of Islamic banks. Thus, Islamic banks in aggregate need to improve their yield on the earning assets to reach to the level of conventional banks.

- Islamic banks need to pay special concern to the level of their liquidity because it is very important as far as banks are considered. They must minimize their all type of expenditures especially reduction in all non-operating expenses is much more needed. This would help Islamic banks to improve their net profit margin and to some extent their cash-to-deposits would also be improved ultimately improving the liquidity position. Finally, the banks must focus to generate more and more advances out of given deposits so that their earning on advances would also improve yield on earning assets.

- Islamic banks need to penetrate more and capture more market than they have done so far. This would help them increase deposits and other liabilities. They should continually create more and more innovative products to attract more prospective customers and investors. This way Islamic bank would increase their solvency by increasing debt compared to equity.

- Islamic banks have to increase its profit rates in deposits and certificate accounts therefore to attract smaller amount of investors.

- Islamic banks have to introduce personal loans as did by conventional banks. (The Issue is being resolving by the Scholars)

- Islamic banks have to promote their banking as many customers still don't know about the Islamic banking system and its reward. Also they have to educate the true concept of Islamic banking so as to attract customers on the basis of its Islamicity. 
- Meezan bank Limited is growing at a faster rate as it has now more than hundred branches in a span of five years. So, others banks also have to take initiatives by promoting their banks.

- Conventional banks have to increase their tenure for giving home loans to their customers. As both Soneri and Mybank are lacking behind the tenure that they are giving for home loans.

- Moreover, both banks have to improve their ATM services, as majority of the ATM machines are not working well, operate their branches in interior cities, provide educational loans to students and improve their customer services.

\section{References}

Anwar, Dr. M (2000), "Islamicity of Banking and Modes of Islamic Banking”, Banquet Hall International Islamic University, Malaysia, viewed 18 April 2008 http://www.thetransitioner.org/wikifr/tiki-download_file.php?fied=32

Ariff, M (2007), "Islamic Banking: A variation of Conventional banking?", Monash Business Review, Vol. 3, no.1, Monash University, Malaysia.

Bonello, F (2005), "Islamic Banking meets conventional banking - A survey of recent developments in banking in Pakistan", Annual Meeting, Charleston, Benedictine University, USA.

Farrukh, Z (2005), "Case Study on Comparative Performance of two Islamic and two Commercial Banks", Market Forces, Vol. 1, no.3, pp. 48-53, PAF-KIET, Karachi. Frequently Asked Questions on "General Islamic Banking", "Car Ijarah" \& "Easy Home" from Meezan Bank Website www.meezanbank.com.

Hassan F, (2007), “Differences between Islamic and Conventional banking”, Meezan Bank Limited, Karachi.

Hempel, GH (1999), Bank Management - Text and Cases, pp. 475-506, Karachi. Hussain, Dr. I (2006), "Evolution of Islamic Banking”, Journal of Islamic Banking \& Finance, Vol. 23, no.3, pp. 73-79, Karachi

Inayat, N (1991), "Thesis on Theory and Practice of Islamic Banking in Pakistan", Department of Economics University of Punjab, Lahore.

Iqbal, M \& Molyneux, P (n.d), “Thirty years of Islamic Banking: History, Performance and Prospects", pp. 72-83, Karachi. 
Kader, JM (2005), “Undergraduate Research on Comparative Financial Performance of Islamic Banks via Conventional Banks in the UAE", U.A.E. University, Al-Ain, UAE.

Khan, F.H. (2008, February 26), Officer-II, (M.A.Sultan, Interviewer) Mehmood, Z (2005), "Islamic Banking: A performance comparison of Islamic bank versus conventional bank in Pakistan”, Bradford School of Management, USA, viewed 10 February 2008,

http://66.102.1.104/scholar?hl=en\&lr=\&q=cache:c1Icebw_DNwJ:virtualscholars.brad .ac.uk:8080/handle/10004/4341

Memon, Dr. NA (2007), “Overview of Islamic Banking in Pakistan”, Journal of Islamic Banking \& Finance”, Vol. 24, no.2, pp.106-112, Karachi.

Nasir, M (2008), "Performance of Islamic Banks", Pakistan \& Gulf Economist, Vol. 27, no.7, p. 57, Karachi.

Nienhaus, Prof. Dr. V (1986), "Islamic Economics, Finance and banking: Theory and Practice”, Quarterly Publication of the International Association of Islamic Banks, Vol. 3, no.2, pp. 36-54, Karachi.

Parvez, IA (1991), “Islamic Banking”, Journal of Islamic Banking \& Finance, Vol. 8, no.1, pp. 17-41, Karachi.

Rahman, UHZHA (n.d), "Differences between Islamic Bank and Conventional bank" viewed 18 February 2008 ,

http://www.zaharuddin.net/index.php?option=com_content\&task=view\&id=297\&Ite mid $=72$

Samad, A (2004), "Performance of Interest free Islamic Banks via Interest based Conventional Banks of Bahrain", IIUM Journal of Economic and Management, Vol. 12, no.2, The International Islamic University, Malaysia.

Samad, A (n.d), “The Performance of Malaysian Islamic Bank during 1984-1997: An Exploratory Study", International Journal of Islamic Financial Services, Vol. 1, no.3, Malaysia.

Usmani, Dr. MIA (2002), Meezan Bank's Guide to Islamic Banking, Darul Ishaat, Karachi. 